\title{
Environmental perception of fishermen: use and conservation of fisheries resources
}

\author{
Lorrane Gabrielle Cantanhêde ${ }^{I * \mathbb{D}}$, Luane Raisa de Moraes Pereira ${ }^{2}$, Polliana Farias Veras ${ }^{3}$, Wallacy Borges \\ Teixeira Silva', Raimunda Nonata Fortes Carvalho-Neta ${ }^{3}$ \& Zafira da Silva de Almeida ${ }^{2}$ \\ ${ }^{1}$ Universidade Federal do Pará, Museu Paraense Emílio Goeldi, Instituto de Ciências Biológicas, Programa de \\ Pós-graduação em Zoologia, Rua Augusto Corrêa, 01, Guamá, Belém, PA, Brasil \\ ${ }^{2}$ Universidade Estadual do Maranhão, São Luís, MA, Brasil \\ ${ }^{3}$ Universidade Estadual do Maranhão, Departamento de Química e Biologia, Programa de Pós-graduação em \\ Recursos Aquáticos e Pesca, Avenida Lourenço Vieira da Silva S/N, Tirirical, São Luís, MA, Brasil \\ *Corresponding author: Lorrane Gabrielle Cantanhêde, e-mail: lorranegabrielle@hotmail.com
}

CANTANHÊDE, L. G., PEREIRA, L. R. M., VERAS, P. F., SILVA, W. B. T., CARVAlHO-NETA, R. N. F., ALMEIDA, Z. S. Environmental perception of fishermen: use and conservation of fisheries resources. Biota Neotropica. 18(4): e20170510. http://dx.doi.org/10.1590/1676-0611-BN-2017-0510

\begin{abstract}
The principal aim was to assess the environmental perception of the fishermen, and implement educational activities, on an island in Brazil. Twelve people between the ages of 23 and 63 were interviewed, of whom $75 \%$ were male, and $58.33 \%$ did not complete their elementary education. Regarding social benefits, $33.33 \%$ receive a family allowance and $16.66 \%$ receive the so-called 'green allowance' (financial assistance to extremely poor families who live in areas of environmental preservation). Fishing remains the main economic activity (58.73\%). The most common types of fishing gear are the 'zangarias' (41.66\%) and 'muruadas' (41.66\%), used to catch white shrimp (Litopenaeus schmitti), the main resource traded on the island (83.33\%). All those interviewed reported a change in the size and weight of the catch in recent years (100\%), and 75\% attribute this to the types of trap used. Talks, films and booklets, as environmental education activities, contributed to community awareness. The population is familiar with the effects of fishing traps, and shows an interest in changing the situation.
\end{abstract}

Keywords: Fishery community, Environmental education, Neotropical Region, Marine environments.

\section{Percepção ambiental de pescadores: uso e conservação dos recursos pesqueiros}

Resumo: O objetivo principal foi avaliar a percepção ambiental dos pescadores e implementar atividades educacionais, em uma ilha no Brasil. Doze pessoas entre as idades de 23 e 63 anos foram entrevistadas, das quais $75 \%$ eram do sexo masculino, e 58,33\% não completou seu ensino fundamental. Em relação aos benefícios sociais, 33,33\% recebem o Bolsa Família e 16,66\% recebem o chamado "Bolsa Verde" (assistência financeira a famílias extremamente pobres que vivem em áreas de preservação ambiental). A pesca continua a ser a principal atividade econômica (58,73\%). Os tipos mais comuns de artes de pesca são as 'zangarias' $(41,66 \%)$ e 'muruadas' (41,66\%), utilizadas para capturar camarão branco (Litopenaeus schmitti), o principal recurso comercializado na ilha $(83,33 \%)$. Todos os entrevistados relataram uma mudança no tamanho e peso da captura nos últimos anos $(100 \%)$ e $75 \%$ atribuem isso aos tipos de armadilhas utilizadas. Conversas, filmes e cartilhas, como atividades de educação ambiental, contribuíram para a conscientização da comunidade. A população está familiarizada com os efeitos das armadilhas de pesca e mostra interesse em mudar a situação.

Palavras-chave: Comunidade pesqueira, Educação ambiental, Região Neotropical, Ambientes marinhos. 


\section{Introduction}

The vast expanse of the Maranhão coastline and its immense biological diversity are favourable to the occurrence of multiple fishery resources, which are exploited by a large variety of equipment and types of fishing, from small-scale fishing without boats, or the use of skiffs or sailing boats, to large vessels (Isaac et al., 2006).

In recent decades, artisanal fishing has been growing due to the setting up of housing in coastal areas, free access to resources, and reduced control and supervision, but mainly due to the lack of other employment opportunities for the riverine population (Haimovici, 2011). According to Almeida et al. (2006), in the State of Maranhão, $15 \%$ of the active population is engaged in fishing, and this has led to conflicts between conservation of the resources and the environment, and the economic development of the population (Haimovici, 2011). However, in order for fishing in Maranhão and in other regions of Brazil not to collapse, institutional management and conservation measures have been implemented, including the creation of Environmental Protection Areas (EPA) and Extractive Reserves (EXRES), with a view to maintaining the natural resources and to integrating man and the environment. It is therefore not enough to consider only the biological and ecological characteristics of these resources, it is also necessary to consider the social and economic aspects involved in exploiting the resources. Through multidisciplinary and integrated studies, it is possible to better understand the economic role of fishing and its impact on the environment (Almeida, 2008).

One of the most common environmental impacts of fishing activities comes from discarding non-target species (Alarcon et al., 2009). This type of practice poses a threat, both to the stocks of target species and to the populations of discarded species that have no attractive commercial value (Zhou et al., 2015). Environmental education, directed towards the resolution of environmental problems as an added dimension to the content and practice of education, can contribute to the minimisation of such impacts.

Environmental perception is a tool to measure and evaluate the environment in which an individual works, in addition to directing their activities and way of life (Evangelista-Barreto, 2014), allowing to evaluate how the community visualizes local aspects related to the exploration of the natural resources, effects of human actions on the environment, benefits derived from biodiversity conservation, and others. According to UNESCO (1973), the different perceptions of culturally distinct individuals, or socioeconomic groups that perform different social roles, are one of the barriers to the protection of natural environments. Therefore, to evaluate the environmental perception to implement environmental education activities is the most effective way of implementing public policies related to the environment and, consequently, to communities that have natural resources for their subsistence (Oliveira and Corona, 2008).

Therefore, using this knowledge to develop community awareness measures and providing the information needed to implement sustainable fisheries and care for the environment, whether for adults or children, is the most effective way to practice environmental education in traditional communities, because it will be based on the causes and motives described by the social actors themselves and in the constructive thinking of suitable methodologies for satisfactory results (Cunha \& Leite, 2009).
Based on these ideas, the aim with this work was to assess the environmental perception of fishermen concerning the impact of 'zangaria' (fixed-trap) fishing, as an aid to the implementation of educational activities for fisheries management in the EXRES of Cururupu.

\section{Material and Methods}

\section{Study area}

The municipality of Cururupu is located on the western coastline of the State of Maranhão in Brazil, and has an area of $495 \mathrm{~km}^{2}$. It comes under the Brazilian System of Conservation Units, with the region included and authorised as an Environmental Protection Area (The so-called Reentrâncias Maranhenses) and Extractive Marine Reserve (Costa et al., 2006).

Created by Presidential Decree on 2 June 2004, the Marine EXRES of Cururupu contains around 185,046 ha, and is part of the Brazilian marine biome, comprising a diverse fauna with almost 1,300 species of fish, 19 of which are endangered and 32 in a state of decline (ICMBIO, 2016). It is made up of 15 islands with an area which is used by traditional extractive populations: Mangunça, Caçacueira, São Lucas, Valha-me-Deus, Guajerutiua, Lençóis, Ponta Seca, Porto Alegre, Retreat, Bate-Vento, Porto do Meio, Mirinzal, Iguará, Beiradão and Peru, the last serving as the study area for this work (Figure 1).

\section{Field activities}

The researchers initially presented the project to the deliberation council of the EXRES to obtain authorisation to carry out the work, and later gave a talk to the residents of Peru Island (Cururupu, in the State of Maranhão) to present the project and to propose a partnership with the residents in carrying out each of the activities, so as to seek solutions for sustainable fishing and to generate information for fisheries management. The talk was also aimed at clarifying technical terms and the results which would be obtained with a scientific project (the breeding of economically important species and the determination of fish diversity in the region) carried out in parallel with this environmental education project under SISBIO license No 47170-1, and with the permission of the Committee for Ethics and Animal Experimentation of the Maranhão State University (Protocol No 016/2014).

In February and March of 2015, to analyse environmental perception in the community, qualitative-quantitative approach was used (Lefèvre and Lefèvre, 2005, Kirschbaum, 2013), seeking a perspective of the social and economic situation, as well as assessing the way the community viewed environmental impacts related to fishing such as wastage and bycatch, solutions for reducing the size of the catch, and the use of selective fishing gear. At this stage, semi-structured questionnaires (Diniz et al., 2011) were used with a sample size of 12 individuals, considered by the community as "key informants", since they demonstrated knowledge acquired locally, either by observation, use or exploration (Sousa et al., 2015). To select the informants, the snow-ball technique was used, in which a first key informant indicates the subsequent one, and so on (Atkinson \& Flint, 2001). The inclusion criteria included people of both sexes that worked with fisheries. 


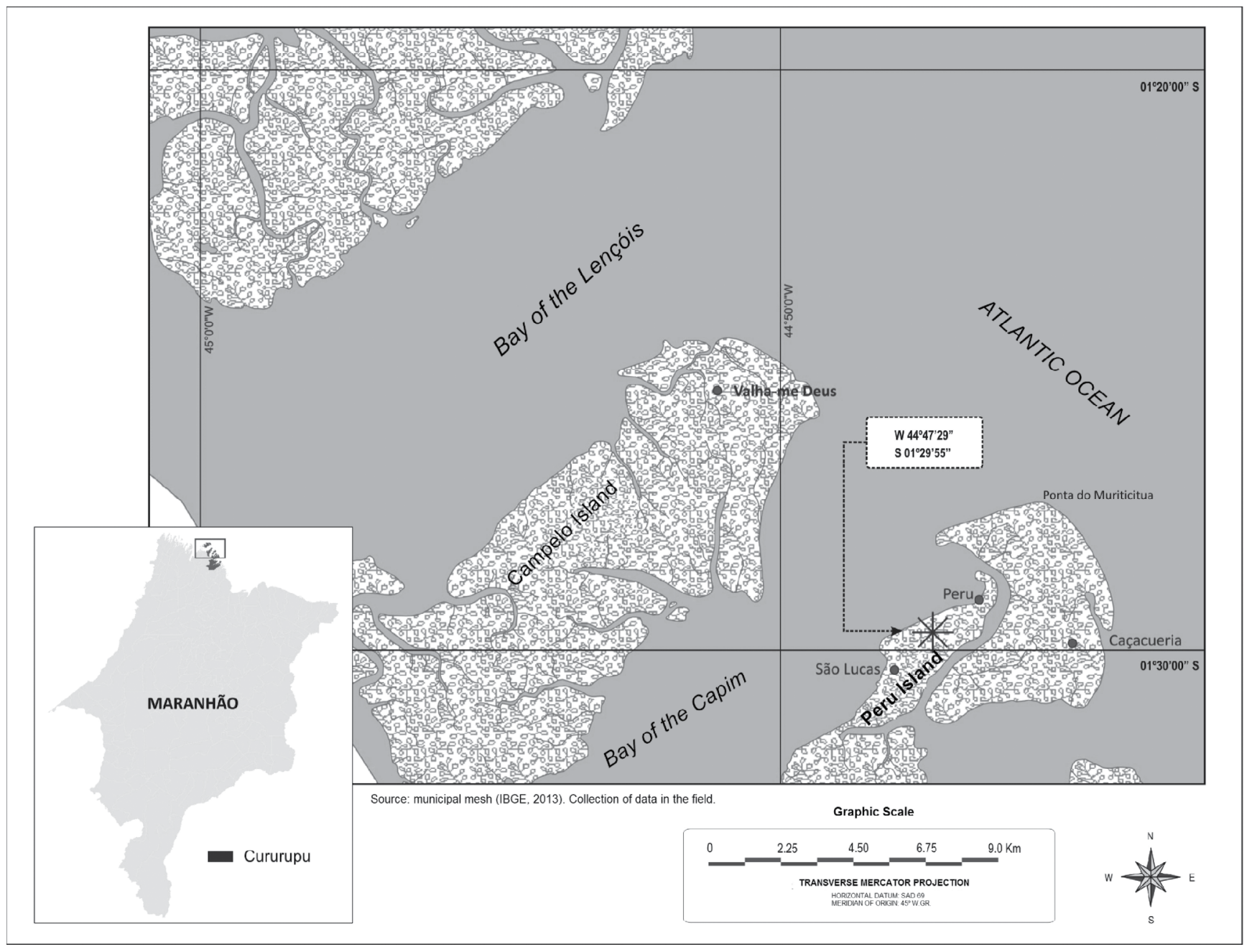

Figure 1. Location of the study area: Peru Island, Cururupu, Maranhão, Brazil.

The sample number represents $25 \%$ of the island's total population and the chosen informants were nominated by the community itself, including island councilors, as the most appropriate people to discuss and report on the local situation.

For the data analysis, a database was created in Microsoft Excel software, where frequency tables that were generated indicated the representativeness of the informants' opinion. Besides, the interviews were recorded and analyzed later, and the most representative discourses were transcribed in original language.

After obtaining the results, an educational booklet was produced, in the form of comics and in accessible language, in which the information obtained was made available in order to keep the population aware of their role in conserving resources. Moreover, the film "Mônica's Gang - A Plan to Save the Planet" (Sousa, 2011) for children, which portrays the conservation of natural resources in a didactic and accessible way, was broadcast. Although the interviews were not conducted with the children, this activity was included based on what was concluded about the knowledge that is transmitted from the parents to the children in the community.

The identification of participants was kept secret, with their names not included in the databases, ensuring the anonymity and confidentiality of the information. We obtained the participation and consent of those involved after clarifying the purpose of the research, their agreement expressed by Informed Consent Form.

\section{Results}

\section{Establishing the initial aims of the research}

At the initial talk, was counted on the participation of the residents, who raised important questions, such as the return of results to the community, benefits of the scientific research (concerning fish diversity in the region and determination of the reproductive period of four economically important species) and the position of the organs responsible (Figure 2).

\section{Profile of the community under investigation}

The age of the informants ranged from 23 to 63 , with a predominance of individuals in the $35-45$ age group, and those $>55$ (33.33\%) who had lived on the island for over 20 years. As seen in several surveys related to fishing, the male sex predominated, representing $75 \%$ of those interviewed. 

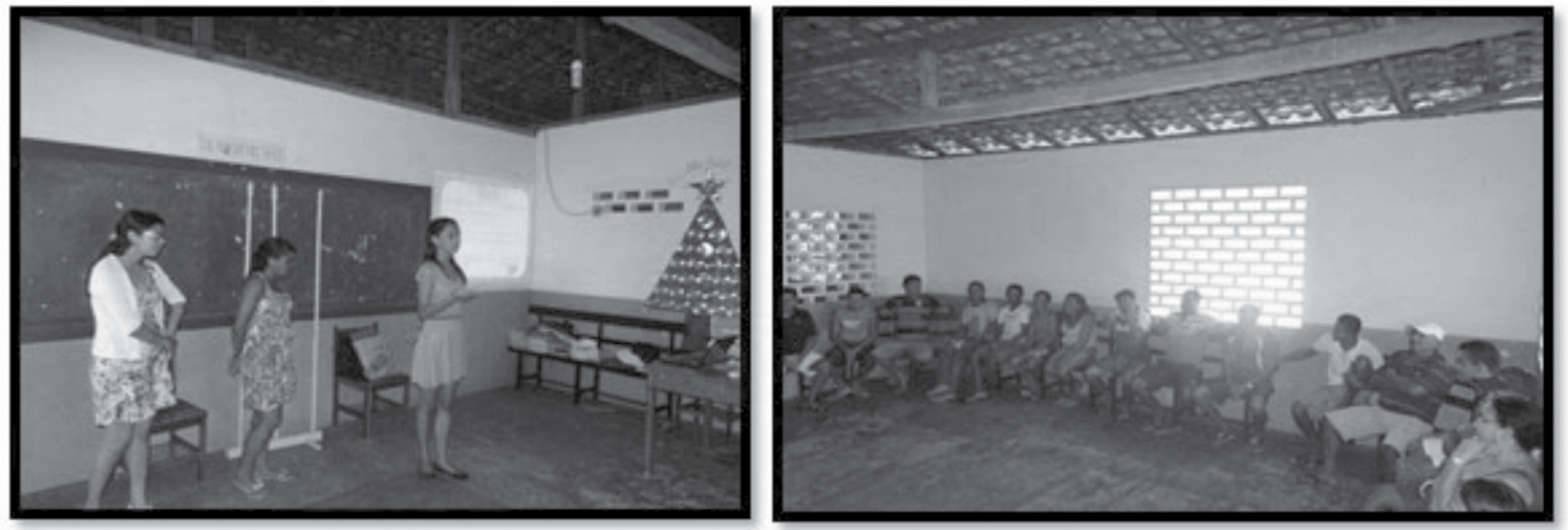

Figure 2. Initial talk to the Peru Island community, Cururupu EXRES, Maranhão, Brazil.

The lack of representation of the female sex can be verified by the testimony of one resident when asked about women's involvement in fishing activities:

"[...] When he gets back from the sea, I help him lay the shrimp in the sun, take them out of the sun... actual fishing, no. Sometimes as I said, I go down to the water's edge."

(Female resident, Peru Island, 51)

In relation to schooling, $58.33 \%$ of those interviewed had not completed elementary education. Most of those interviewed receive no kind of social benefit, and among those who do, the Family Allowance was the most represented, at $33.33 \%$ (Table 1).

We noted a great appreciation of social benefit by the respondents, who said that the benefit came in useful when helping to pay expenses, since fishing is an unstable source of income, where some periods are more productive than others are.

Almost $60 \%$ of those interviewed work in fishing, an indication that this is the principal economic activity on Peru Island.

Among the types of fishing gear used by the fishermen are the so-called 'zangaria', 'tarrafa', 'curral', 'muruada'4 e and 'puçá'. The 'zangarias' (41.66\%) and the 'mouaries' (41.66\%) are the most common types of fishing gear. We noticed that the fish are used mainly for personal consumption or sold at a lower value, and that shrimp is the most commercially valued product $(83.33 \%)$, explaining the results found for the fishing gear.

The most traded species according to the fishermen are White shrimp (Litopenaeus schmitti), King Weakfish (Macrodon ancylodon), Coco sea catfish (Bagre bagre), Whitemouth Croaker (Micropogonias furnieri), Crucifix sea catfish (Sciades proops), Tripletail (Lobotes surinamensis), Parassi mullet (Mugil incilis) and Common Snook (Centropomus undecimalis).
Family income, for the most part, does not exceed the minimum wage $(41.67 \%)$, but a large number explained that there was no way to state that with conviction (Table 2) since the monthly income from fishing activities is highly variable due to fluctuations in the product, ranging from the minimum wage (BRL 788.00 - USD 291.85 [in 2015]) to four minimum wages (BRL 3,152.00 - USD 1,167.40 [in 2015]).

Regarding perceived changes in the size and weight of the fish, $100 \%$ of the respondents said that these aspects have changed over the years. A total of $69.2 \%$ related this to the intense exploitation of resources due to the use of selective fishing gear and the removal of juvenile individuals that have not yet seen an increase in weight or length, and are therefore considered unsuitable for consumption.

"The change is because they are catching very small fish... all kinds of fish ... there is no time to grow, they catch them early to sell. As I say, there is a lot of fish."

(Resident, 37)

Around $75 \%$ of those interviewed said that the traps used by the community cause damage, and that the weighted nets ${ }^{6}$ used by fishermen from neighbouring communities end up hampering fishing in the Peru Island community.

On the other hand, some respondents also consider the trawl net and high trap (zangaria alta) to be harmful types of fishing gear.

"Man, it causes damage, right, because actually the fixed trap... it always kills both the big and small fish, right?! And other types of fishing, the high trap ... that's a really high net. Whatever is there is caught. We don't have it here, but they come from another places to fish here, understand?! They put it right at the edge of the mangrove".

(Resident, 33)

\footnotetext{
${ }^{1}$ A fixed trap placed at the ebb tide, when stakes are set up to mark out the maximum points of a semicircle. Stakes marking the minimum points of the semicircle are only set up at low tide, when the expanse is completely exposed (Almeida, 2008).

${ }^{2}$ A small circular net with lead weights on the lower part called the bag, where the fish are held (Almeida, 2008).

${ }^{3}$ An enclosure of pieces of fabric and sticks, tied to stakes with liana. It is divided into two sections, known as the 'room' and the 'pen'. The room is where the fish lose orientation, and due to the current, are no longer able to get out, entering the pen where they are trapped (Almeida, 2008).
} 
Environmental perception of fishermen

Table 1. Socioeconomic data of the fishing community of Peru Island, Cururupu EXRES, Maranhão, Brazil.

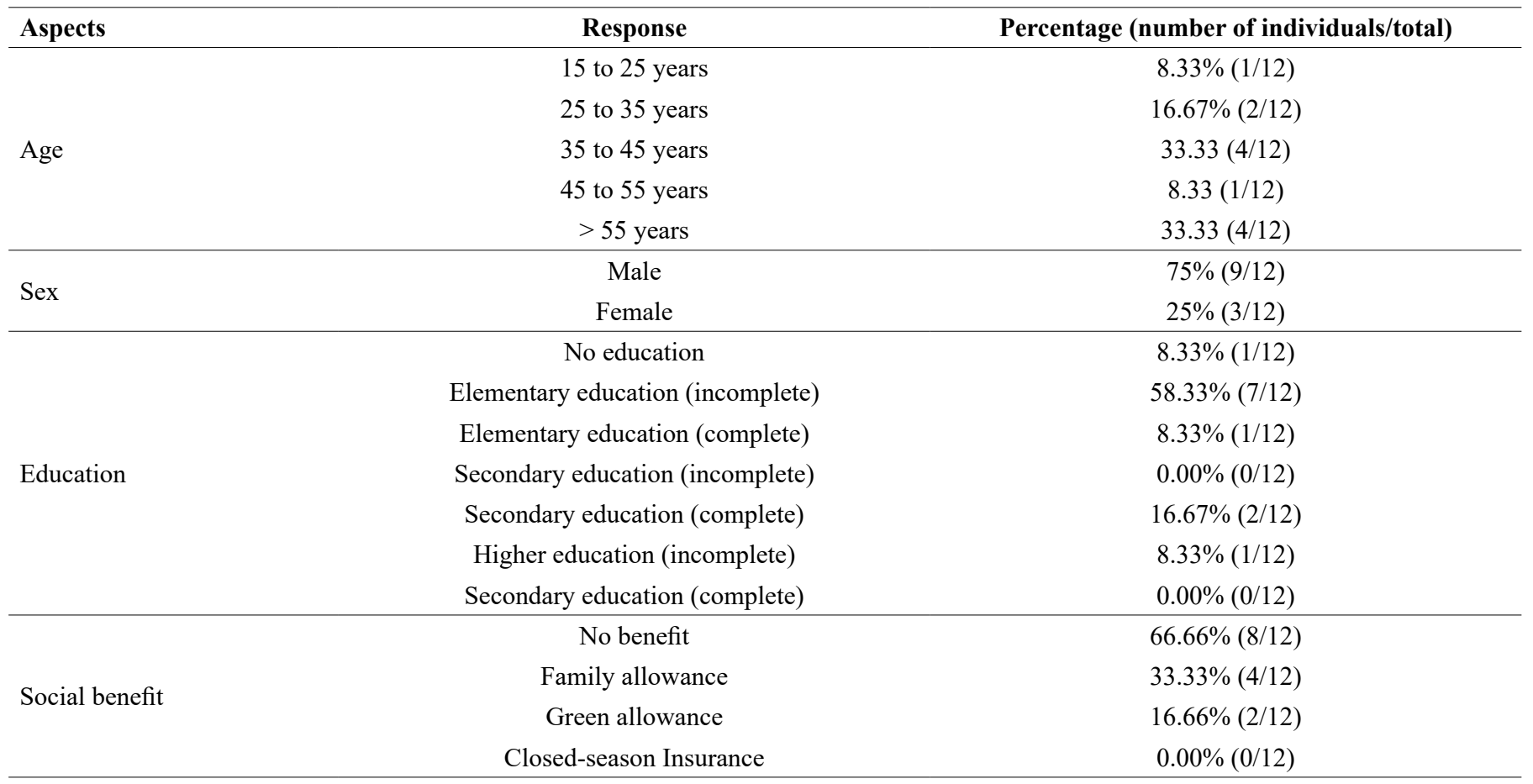

Table 2. Fishing economic data of the fishing community of Peru Island, Cururupu EXRES, Maranhão, Brazil.

\begin{tabular}{|c|c|c|}
\hline Aspects & Response & Percentage (number of individuals/total) \\
\hline \multirow{3}{*}{ Working in fishing } & Yes & $58.33 \%(7 / 12)$ \\
\hline & No & $25.00 \%(3 / 12)$ \\
\hline & Occasionally & $16.67 \%(2 / 12)$ \\
\hline \multirow{5}{*}{ Fishing gear } & Zangaria & $41.66 \%(5 / 12)$ \\
\hline & Tarrafa & $25 \%(3 / 12)$ \\
\hline & Curral & $8.33 \%(1 / 12)$ \\
\hline & Muruada & $41.66 \%(5 / 12)$ \\
\hline & Puçá & $8.33 \%(1 / 12)$ \\
\hline \multirow{9}{*}{ Principal species caught for sale } & Shrimp & $83.33 \%(10 / 12)$ \\
\hline & King Weakfish & $33.33 \%(4 / 12)$ \\
\hline & Coco sea catfish & $25 \%(3 / 12)$ \\
\hline & Whitemouth Croaker & $8.33 \%(1 / 12)$ \\
\hline & Crucifix sea catfish & $16.66 \%(2 / 12)$ \\
\hline & Tripletail & $16.66 \%(2 / 12)$ \\
\hline & Parassi mullet & $8.33 \%(1 / 12)$ \\
\hline & Common Snook & $8.33 \%(1 / 12)$ \\
\hline & Whitefish & $8.33 \%(1 / 12)$ \\
\hline \multirow{5}{*}{ Family income } & $<1$ minimum salary & $41.67 \%(5 / 12)$ \\
\hline & 1 minimum salary & $25.00 \%(3 / 12)$ \\
\hline & Between 1 and 4 minimum salaries & $8.33 \%(1 / 12)$ \\
\hline & 5 or more minimum salaries & $0.00 \%(0 / 12)$ \\
\hline & Variable & $25.00 \%(3 / 12)$ \\
\hline
\end{tabular}

\footnotetext{
${ }^{4}$ A semi-fixed trap that is placed against the current in holes and small streams, with stakes set up about $1.5 \mathrm{~m}$ apart, in the apparent form of a wall (Almeida, 2008).

${ }^{5}$ Funnel-shaped nets for shrimp fishing. The net is tied to two pieces of wood so that it can be dragged (Almeida, 2008).

${ }^{6}$ Type of holding net, where many weights are used to fix the net to the sides of channels to prevent free circulation of the water (BRASIL, 2014).
} 
"It's bad. Fishing with nets, they're doing away with the fish there in the river. Trawling ... causes a lot of damage here. They trawl the river, there are times we go and don't even catch enough to eat. They're "squeezing the fish out", as we say here".

(Resident, 39)

Regarding a possible solution to the visible reduction in fish, $25 \%$ of respondents pointed to the closed season, and another $25 \%$ stated that the problem has no solution. Some of those interviewed pointed to a reduction in the number of nets and a change in the current closed season as possible solutions.

Currently, the closed season in the Cururupu EXRES is from June to August; this corresponds to the migration of the sardines and not to the reproductive period of the fish.

The residents themselves stated during the interviews that June to August is the wrong period as that is when the fish are of a good size for fishing.

"They should have come to do the research, because the one time that is good for fishing, they are prohibiting it; it's the wrong time."

(Female resident, 31)

One resident also drew attention to better enforcement of the regulations with punishment for those who disagree:

"Besides having the ban when you can't fish, we believe there has to be control anyway, and punishment for those people who 'may disagree' with the management agreement in this notice that arrived. Because if I call a meeting of the community to get rid of a fisherman's net from here, very soon we are going to have trouble, and at the moment not even the law gives supports us, it doesn't punish that fisherman, it won't help at all. So we need control and punishment for anyone who disagrees with the management agreement."

(Resident, 23)

A total of $81.8 \%$ of those interviewed said that they did not notice any type of pollution on the island; this result being directly related to receipt of the Green Allowance benefit (financial assistance to extremely poor families who live in areas of environmental preservation). Regarding guidance on the minimum catch size for the most traded fish, around $50 \%$ said that there had been a meeting where this information was passed on, and $50 \%$ say that there is no regulation for a minimum catch size (Table 3 ).

In an attempt to get them to reflect on the environmental problems that may affect or are affecting the island, we asked how they imagined the environment in which they lived 20 years from now. The majority answered that the situation would be more critical than it is today and that resources would be more scarce.
"That's right ... if no one is worried and there is not even the law to take the necessary measures, I think we probably won't have as much as we had before; even today I don't see so much anymore, we only have something now through divine help. But if you say it's because of our own awareness, that it's improving because of us, because we are taking care of the reservation, then it's a lie because that's not happening. It's the old question 'only the smartest survive,".

(Resident, 23)

\section{Didactic tools used with the community}

At the end, we gave the children and adults an educational booklet with information obtained scientifically and from actions carried out throughout the year, which serves as a basis for current and future fishing activities, and to reflect on how each one can contribute to the sustainability of Peru Island. The contents include fish diversity in the region, information on the reproductive biology of four economically important species, the final destination of the specimens taken to the laboratory, photographs, reflections of the residents themselves during the interviews, and finally, a look at the local situation 10 years from now with the collaboration of the community (Figure 3 ).

After the screening of the film "Monica's Gang - A Plan to Save the Planet", it was noticed that the children had learned important lessons regarding the disposal of solid wastes and contaminants in the aquatic environment and the consequences of that for fishing. To evaluate this learning, one wondered what would be done with plastic cups and bags used for food and beverage consumption during the film. They replied that they would apply the logic of the three R's that was taught during the film: reduce and reuse, using only a glass; and recycle, to produce some kind of garnish or handicraft.

\section{Discussion}

Throughout the research, it was noticed that the population is aware of the effects caused by the fishing traps and show interest in transforming this reality. This perception of the fishing community was the initial step so that the actions of environmental education could collaborate in the process of knowledge construction, conservation of fishing resources, and sensitization of local social agents.

The longer the time lived in an area, the greater the level of knowledge and familiarity with that area, therefore, people of more advanced age are best suited to talk about local activities and the environment as a whole. According to Silvano and Begossi (2012), there is an accumulation of knowledge with the passing years, so that older people tend to know more about matters of interest to the community, and are considered the most suitable because of that knowledge.

Because fishing is still a traditionally male activity, we saw a greater representation of men. Similar results were reported by Santos et al. (2011) in the fishing community in the town of Raposa, Maranhão, stating that this pattern is the result of the need for great physical effort in fishing activities and of the danger, both of which end up being limiting for women. According to Costa (2009), only now are women beginning to show interest in the activity together with their husbands, sometimes 
Environmental perception of fishermen

Table 3. Environmental perception data of the fishing community of Peru Island, Cururupu EXRES, Maranhão, Brazil.

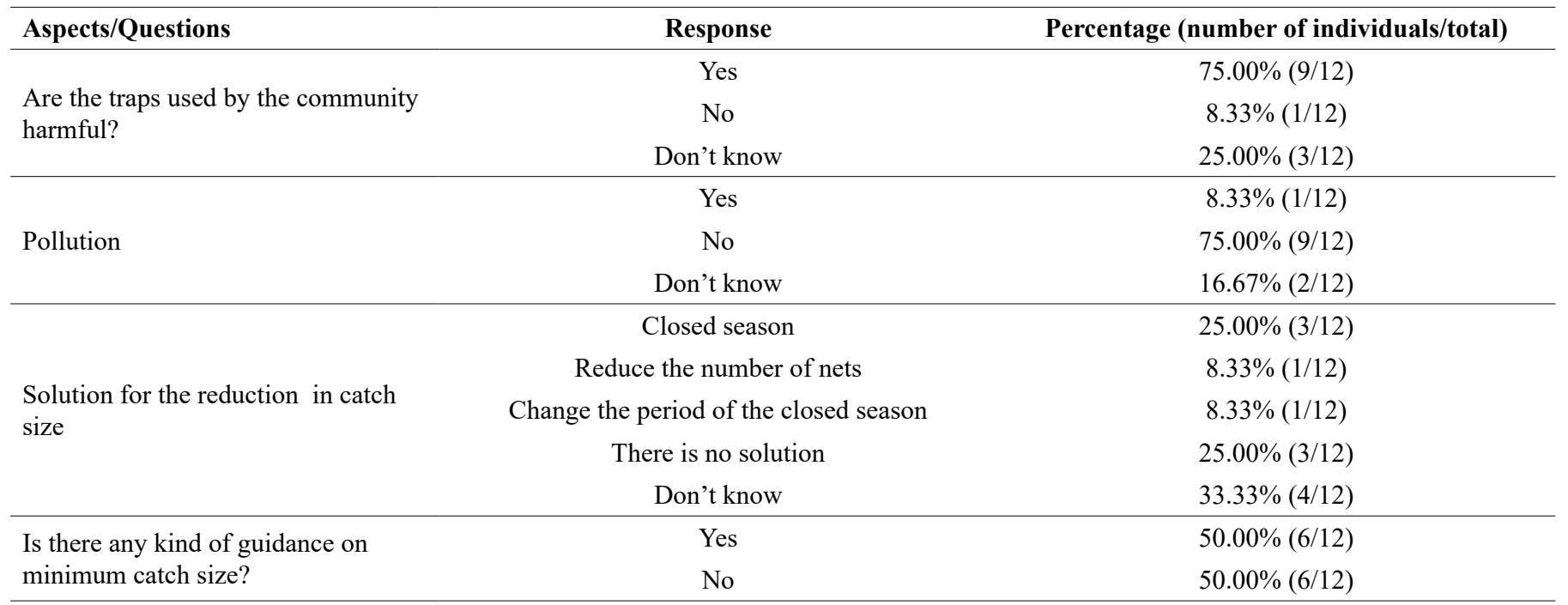
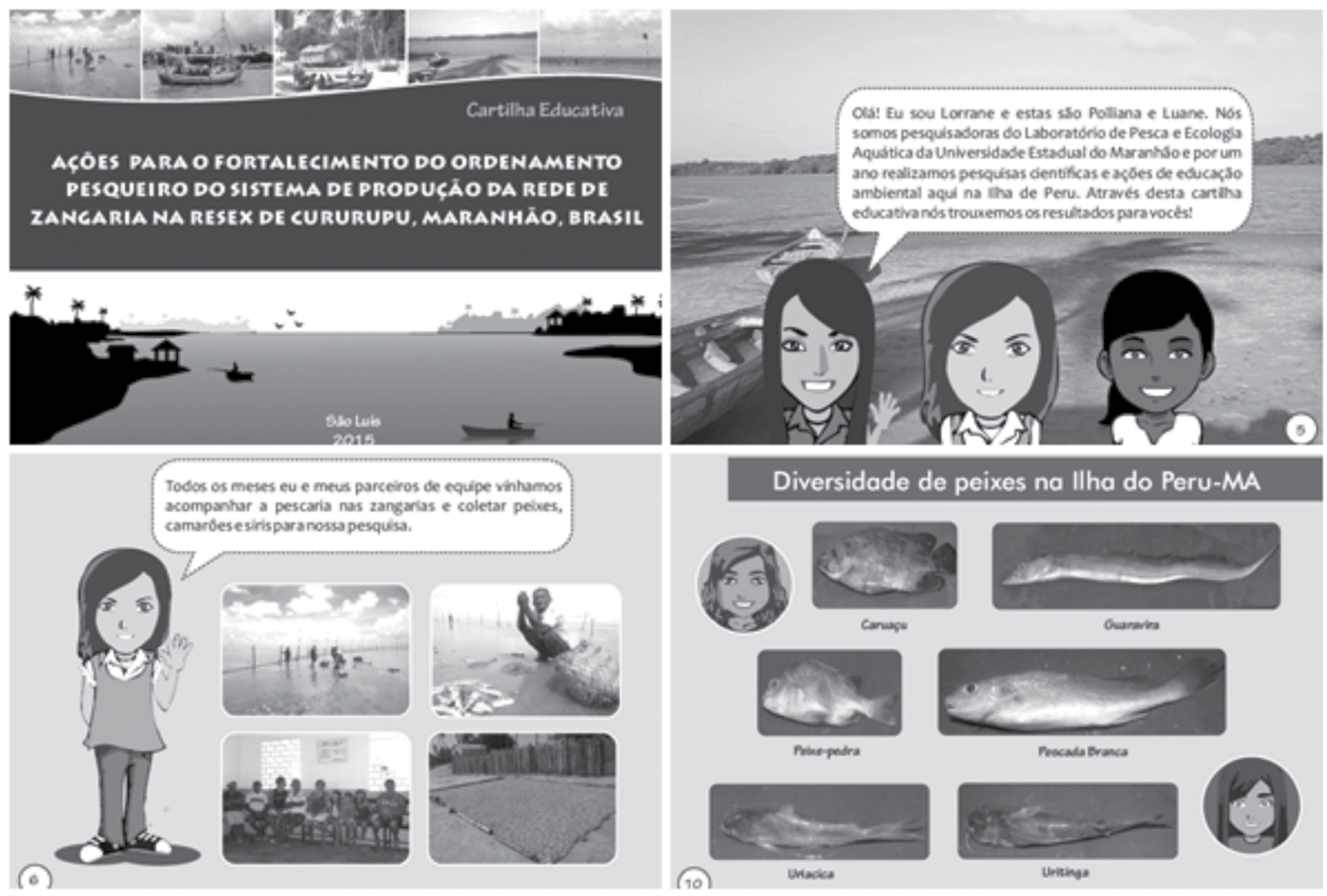

Figure 3. Part of the educational booklet produced from results obtained during the project. Graphic design and illustration: Yuri Almeida.

leaving off other activities such as handicrafts or even household chores. However, their main function is still to clean the fish, organise the gear and prepare the food (Knox and Firme, 2016).

The results found for level of schooling may be related to the geographic isolation imposed on the inhabitants of an island, or to the economic conditions, where children and grandchildren end up starting fishing activities early, either to help or to support the family. The results found by Santos et al. (2011) in the town of Raposa, support this, since the author found a higher level of schooling among the younger fishermen, and related this to the proximity of the state capital, São Luís, where transportation is regular and more schools are available. 
The fact that fishing is still the most predominant activity in the community can be explained by the richness and abundance of the resources occurring at the site, and by the conditions, which are favourable to fishing. However, fishing is considered an activity of unstable return, and fishermen and their families therefore supplement their income with financial aid provided by the government and with other types of activities, such as tourist transport and the sale of handicrafts. This way of working in fishing communities is common in other regions of the Amazon (Ceregato and Petrere Jr., 2003, Cardoso et al., 2004, Ruffino, 2005, Lima et al., 2012). Furtado (1993) states that artisanal fishermen are known for being multitalented, due to the extensive range of work they carry out daily, where they mix several activities so as to guarantee the sale of various products and generate a minimum income.

Shrimp as the target product is directly related to the types of fishing gear used and the size of the net opening. This practice may have future impact on the region, since fish of all sizes are caught, including juveniles, which end up not being used for sale or consumption, and are discarded on a large scale (Alarcon et al., 2009, Leitão et al., 2014, Klautau et al., 2016).

As the "zangaria" (fixed trap) is already prohibited in the country, with Maranhão being one of the only states where it is still allowed (with activities suspended from June to August), the fear of a possible ban may have influenced the questions on harmful fishing gear. According to Pereira (2008) and Golden et al. (2016), the daily need for food is the main reason why fishing is increasingly more intense. The shortage of resources leads to the use of nets of a finer-mesh with the aim of capturing smaller species to achieve results similar to earlier scenarios. As a result, there is greater damage to the environment, compromising stocks and jeopardising future catches.

The closed-season insurance benefit, implemented by the Ministry of Labour and Employment, where fish, shrimp and lobster fishermen receive a minimum wage not to fish during the reproductive period of the species (Cavalcante et al., 2013), is not received by any of those interviewed. Difficulties in delivering and checking documents are the main reasons for the delay in implementing this aid.

Adequate cleaning of the environment is related to the Green Allowance benefit received by the residents, encouraging them to carry out collective clean-ups and meetings to organise the disposal of garbage. The Green Allowance Environmental Conservation Support Program (Programa de Apoio à Conservação Ambiental Bolsa Verde), instituted by Law No 12,512 of 14 October 2011, and regulated by Decree No 7,572 of 28 September 2011, grants a benefit of BRL 300 every quarter to families in situations of extreme poverty that live in areas considered a priority for environmental conservation. Around $47 \%$ of the 16.2 million people living in extreme poverty are in rural areas, so the specific aim is to reconcile an increase in the income of this population to the preservation of ecosystems and the sustainable use of natural resources (Brazil, 2011). This new benefit, part of the Brazil Without Poverty Program (Programa Brasil Sem Miséria), is intended for those who develop activities for the sustainable use of natural resources in Extractive Reserves, National Forests, Federal Sustainable Development Reserves and the Environmentally Differentiated Settlements of the Agrarian Reform (Brazil, 2011, Pereira et al., 2016).
Regarding the local knowledge about the impacts of activities on fish resources and on the environment, it was possible to perceive that fishermen are aware that the fish stocks are decreasing and that affects the standard of living of those who depend solely on the activity to survive. However, most do not consider themselves responsible for this and do not consider the fishing gear used to pose any risk, except for those used by neighboring communities. It was also noticed that the community does not know how to react to the problem of fish reduction and, moreover, there are those who consider that the reduction of fish is a momentary phenomenon, making clear the need for lectures and informative courses about the consequences of unsustainable fishing. It was noted that there is already some empirical knowledge about the need to allow the reproduction and growth of the animals, since the community indicates the closure as a solution for the reduction of fishes and crustaceans.

Our environmental education activities included giving talks, films for children and delivering educational booklets, and they proved to be good tools for raising awareness in the community, since besides being informative, they led the residents to reflect on their present attitudes and the implications for the future. The booklet, produced in the form of comic strips and in simple language, also covered the child audience, who are the future fishermen of the region. Van Bressem et al. (2006) pointed out that the use of educational booklets is an extremely valuable tool in education, as biological information is presented in the form of a story that is easy to understand and remember. In addition, they can be read at any time and lent to other people. The cinema and the production of images gain strength in the contemporary world, appearing as a powerful tool of socialization of information and being able to function as special sources of education and knowledge construction (Oliveira, 2006, Fischer, 2009). According to Otto and Pensini (2017), in childhood the motivation to be ecologically friendly is formed and probably the effect lasts a lifetime (Evans et al., 2007).

Finally, the scenario 20 years from now as described by the residents themselves, shows a more critical situation than the current one, with scarcer resources and the search for new forms of livelihood. In this way, we can see a clear need for intervention by both the authorities and residents, as well as educational activities, and activities to raise awareness promoted by educational institutions and by governmental and non-governmental agencies.

\section{Acknowledgements}

The team wishes to thank the Maranhão Foundation for Scientific Research and Development (FAPEMA) for funding the project (Public Notice AEXT 1714). The team also wishes to thank the Committee of the Cururupu Extractive Reserve for their permission to carry out the project, and the fishermen for their involvement and collaboration. Our thanks also go to the State University of Maranhão for providing logistical support and transportation and Jefferson Horley for the English revision.

\section{Authors' Contributions}

Lorrane Gabrielle Cantanhêde: Substantial contribution in the concept and design of the study; contribution to data collection; contribution to critical revision, adding intelectual content. 
Luane Raisa De Moraes Pereira: Substantial contribution in the concept and design of the study; contribution to data collection; contribution to critical revision, adding intelectual content.

Polliana Farias Veras: Substantial contribution in the concept and design of the study; contribution to data collection.

Wallacy Borges Teixeira Silva: Contribution to data collection.

Raimunda Nonata Fortes Carvalho-Neta: Contribution to critical revision, adding intelectual content.

Zafira Da Silva de Almeida: Substantial contribution in the concept and design of the study; contribution to critical revision, adding intelectual content.

\section{Conflicts of interest}

The authors declare that they have no conflict of interest related to the publication of this manuscript.

\section{References}

Alarcon, D.T., Costa Dâmaso, R.C.S. \& Schiavetti, A. 2009. Abordagem etnoecológica da pesca e captura de espécies não-alvo em Itacaré, Bahia (Brasil). Bol. Inst. Pesca 35(4): 675 - 686.

Almeida, Z.S., Castro, A.C.L., Paz, A.C., Ribeiro, D., Barbosa, N. \& Ramos, T.D. 2006. Diagnóstico da pesca artesanal no litoral do estado do Maranhão. In A Pesca Marinha e Estuarina do Brasil no Início do Século XXI: recursos, tecnologias, aspectos socioeconômicos e institucionais (V.J. Isaac-Nahum, A.S. Martins, M. Haimovici \& J.M.Andrigueto-Filho, eds). Editora UFPA, Belém, p.41-66.

Almeida, Z.S. 2008. Os recursos pesqueiros marinhos e estuarinos do Maranhão: biologia, tecnologia, socioeconomia, estado da arte e manejo. Tese de doutorado, Universidade Federal do Pará, Belém.

Atkinson, R. \& Flint, J. 2001. Accessing hidden and hard-to-reach populations: snowball research strategies. Social Research Update 33: 1-4.

BRAZIL. 2011. Decreto ${ }^{\circ} 7.572$, de 28 de setembro de 2011. Diário Oficial da República Federativa do Brasil. Acesso em: 18 de Junho de 2016.

ICMBIO. 2016. Biomas brasileiros marinhos. ICMBIO Portal. Acesso em: 23 de Fevereiro de 2016.

Cardoso, R.S., Batista, V.S., Faria Junior, C.H. \& Martins, W.R. 2004. Aspectos econômicos e operacionais das viagens da frota pesqueira de Manaus, Amazônia Central. Acta Amazon. 34(2): 307-313.

Cavalcante, A.L., Pires, M.M., Strenzel, G.M.R. \& Ferraz, M.I.F. 2013. A arte da pesca: análise socioeconômica da Reserva Extrativista de Canavieiras, Bahia. Inf. Gepec 17 (2): 81-99.

Ceregato, A. S. \& Petrere Jr., M. 2003. Financial comparisons of the artisanal fisheries in Urubupungá complex in the middle Paraná river (Brazil). Braz. J. Biol. 63(4): 673-682.

Costa, M.R.P., Alcântara, E.H., Amorim, A.J.E. \& Mochel, F.R. 2006 Avaliação das potencialidades e fragilidades das áreas de manguezal para a implementação do ecoturismo usando ferramentas de sensoriamento remoto em Cururupu - MA, Brasil. Caminhos de Geografia 22(17): 237 - 243.

Costa, R.V. 2009. Percepção ambiental de pescadores do Rio Teles Pires em Alta Floresta - MT: Um diálogo com a educação ambiental. Dissertação de mestrado, Universidade do Estado de Mato Grosso, Cáceres.

Cunha, A.S. \& Leite, E.B. 2009. Percepção Ambiental: Implicações para a Educação Ambiental. Sinapse Ambiental 3:66-79.

Diniz, M.T.M., Vasconcelos, F.P., Maia-Vasconcelos, S.M. \& Rocha, G.C. 2011. Utilização de entrevistas semi-estruturadas na gestão integrada de zonas costeiras o discurso do sujeito coletivo como técnica auxiliar. Scientia Plena 7(1): 1-8.
Evangelista-Barreto, N. S., Daltro, A.C.S., Silva, I.P. \& Bernardes, F.S. 2014. Indicadores socioeconômicos e percepção ambiental de pescadores em São Francisco do Conde, Bahia. Bol. Inst. Pesca 40(3): 459-470.

Evans, G.W., Brauchle, G., Haq, A., Stecker, R., Wong, K. \& Shapiro, E. 2007. Young Children's Environmental Attitudes and Behaviors. Environ. Behav. 39(5): 635-659.

Fischer, R.M.B. 2009. Docência, cinema e televisão: questões sobre formação ética e estética. Rev. Bras. Educ. 14(40): 93-102.

Furtado, L.G. 1993. Pescadores do rio Amazonas: um estudo antropológico da pesca ribeirinha numa área amazônica. Museu Paraense Emílio Goeldi, Belém.

Golden, C.D., Allison, E.H., Cheung, W.W., Dey, M.M., Halpern, B.S., McCauley, D.J., Smith, M., Vaitla, B., Zeller, D. \& Myers, SS. 2016. Nutrition: Fall in fish catch threatens human health. Nature 534(7607): 317-20.

Haimovici, M. 2011. Sistemas pesqueiros marinhos e estuarinos do Brasil: caracterização e análise da sustentabilidade. Editora Furg, Rio Grande.

Isaac, V.J., Martins, A.S., Haimovici, M. \& Andriguetto-Filho, J.M. 2006. A pesca marinha e estuarina do Brasil no início do século XXI: recursos, tecnologias, aspectos socioeconômicos e institucionais. Editora UFPA, Belém.

Kirschbaum, C. 2013. Decisões entre pesquisas quali e quanti sob a perspectiva de mecanismos causais. Rev. Bras. Ciênc. Soc. 28(82): 179-257.

Klautau, A.G.C.M., Cordeiro, A.P.B., Cintra, I.H.A., Silva, L.E.O., Carvalho, H.R.L. \& Itó, L.S. 2016. Impacted biodiversity by industrial piramutaba fishing in the amazon river mouth. Bol. Inst. Pesca 42(1): 102-111.

Knox,W. \& Firme, R.M. 2016. Mulheres na atividade pesqueira no Espírito Santo. Gênero 16(2): 219-235.

Lefèvre, F. \& Lefèvre, A.M.C. 2005. Depoimentos e discursos: uma nova proposta de análise em pesquisa social. Liberlivro, Brasília.

Leitão, F., Range, P. \& Gaspar, M.B. 2014. Survival estimates of bycatch individuals discarded from bivalve dredges. Braz. J. Oceanogr. 62(4): 257-263.

Lima, M.A.L., Doria, C.R.C. \& Freitas, C.E.C. 2012. Pescarias artesanais em comunidades ribeirinhas na Amazônia brasileira: perfil socioeconômico, conflitos e cenário da atividade. Ambient. Soc. 15(2): 73-90.

Oliveira, B.J. 2006. Cinema e imaginário científico. Hist. cienc. saudeManguinhos 13: 133-50.

Oliveira, K.A. \& Corona, H.M.P.A. 2008. Percepção ambiental como ferramenta de propostas educativas e de políticas ambientais. ANAP Brasil - Revista Científica 1(1): 53-72.

Otto, S. \& Pensini, P. 2017. Nature-based environmental education of children: Environmental knowledge and connectedness to nature, together, are related to ecological behavior. Glob. environ. change 47: 88-94.

Pereira, M.O.R. 2008. Educação Ambiental Com Pescadores Artesanais: Um Convite À Participação. Prax. Educ. 3(1): 73 - 80

Pereira, M.P., Botelho, M.I.V., Condé, M.F. \& Ferreira, S.C. 2016. A efetividade social do programa Bolsa Verde de Minas Gerais. Estud. debate 23(1): 180-191.

Ruffino, M. L. 2005. Gestão do uso dos recursos pesqueiros na Amazônia. IBAMA - ProVárzea, Manaus.

Santos, P.V.C.J., Almeida-Funo, I.C.S., Piga, F.G., França, V.L., Torres, S.A. \& Melo, C.D.P. 2011. Perfil socioeconômico de pescadores do município da Raposa, estado do Maranhão. Revista Brasileira de Engenharia de Pesca 6 (1): 1-14.

Silvano, R.A.M. \& Begossi, A. 2012. Fishermen's local ecological knowledge on Southeastern Brazilian coastal fishes: contributions to research, conservation, and management. Neotrop. ichthyol. 10:133-147.

Sousa, R.F., Silva, R.A.R., Rocha, T.G.F., Santana, J.A.S. \& Vieira, F.A. 2015. Etnoecologia e etnobotânica da palmeira carnaúba no semiárido brasileiro. Cerne 21(4): 587-594. 
Um plano para salvar o planeta. Direction and Production of Maurício de Sousa. São Paulo: Maurício de Sousa, 2011. Available from: $<$ https://www.youtube. com/watch? $v=$ L3zaoUaHJhQ $>$. [Accessed on: 11/12/2014].

UNESCO. 1973. Rapport Final du groupe d'experts sur le project 13: La perception de la quilité du milieu dans le Programme sur I'homme et la biosphère (MAB). Unesco, Paris.
Van Bressem, M.F., Alfaro-Shigueto, J., Geysen, K., Ontón, K., Vega, D., Chávez-Lisambart, L. \& Van Waerebeek, K. 2006. Dolphins and Children: A Blueprint for Marine Environmental Education in Peru. Applied Environmental Education \& Communication 5 (3): 183-191.

Zhou, S., Smith, A.D.M. \& Knudsen, E. 2015. Ending overfishing while catching more fish. Fish. Fish. 16: 716-722.

Received: 28/12/2017

Revised: 07/04/2018

Accepted: 29/06/2018

Published online: 16/07/2018 